\title{
Turning concepts into community driven catchment water management solutions: Foreword to the special HELP edition"
}

\author{
Shahbaz Khan \\ Presently Global Coordinator HELP, Division of Water Sciences, UNESCO, 1, rue Miollis 75732 Paris cedex 15, SP France
}

\section{Background}

This special volume consists of selected papers from the Symposium titled 'HELP in Action: Local Solutions to Global Water Problems - Lessons from the South' which was held at the Emperor's Palace, Johannesburg, South Africa from 4 to 9 November 2007. This symposium was ably hosted by the Department of Water Affairs and Forestry (DWAF) South Africa, in partnership with the International Water Management Institute (IWMI), the Water Research Commission (WRC), the Water Institute of Southern Africa (WISA) and the University of KwaZulu-Natal (UKZN).

HELP is an acronym for the Hydrology for Environment, Life and Policy which is a crosscutting programme under the International Hydrology Program (IHP) of UNESCO. The HELP programme was initiated by the international hydrological research community and adopted by UNESCO and WMO in 1999. HELP is designed to develop scientific research in the application of integrated water resource management (IWRM) through a global network of catchments to improve the links between hydrology and the needs of society. It seeks examples of good solutions-oriented science which can deliver real outcomes and impacts to real people in real catchments to address real problems, locally as well as globally.

HELP philosophy can be best illustrated by reference to Gibbons et al. (1994) who distinguish two approaches to knowledge production: traditional research is Mode 1, in which there are narrow fields of study and separate roles, with academics developing the knowledge and passing it on to the practitioners. In Mode 2, knowledge is produced by a trans-disciplinary team that includes the practitioner, and the learning is immediate for all - it is part of the discovery process. The role of the practitioner is central to Mode 2 throughout the entire research process. The HELP initiative is encouraging Mode 2 knowledge generation and adoption.

Currently there are 67 HELP basins across the globe (in Australia, Asia, Africa, North America and Latin America (www.unesco.org/water/ihp/help/) to demonstrate how HELP principles can be put in practice. These basins are divided into 4 categories based on the level of development in relation to the ideals of bringing all aspects of water use together - people, production, environment, policy and science. The current HELP Network involves more than 50 Member States of UNESCO.

The Symposium offered a review of progress towards the implementation of Integrated Water Resource Management by

\footnotetext{
Revised paper. Originally presented at the symposium 'HELP in Action: Local Solutions to Global Water Problems - Lessons from the South' which was held at the Emperor's Palace, Johannesburg, South Africa from 4 to 9 November 2007.

* To whom all correspondence should be addressed.

+331456845 69; fax: +331456858 11;

e-mail: s.khan@unesco.org
}

taking a stock of over 8 years of HELP activities in real catchments while seeking real solutions with real people building on earlier successes (e.g. Andersson et al., 2004; Falkenmark, 2004; Khan, 2004 and Schulze et al., 2004). The learning and sharing of best practice experience amongst HELP basins have greatly benefited attempts as a global community to improve the sustainable management of water resources through continuous dialogue and involvement of stakeholders from the community to government level.

Over 180 delegates from 26 countries attended this symposium. These delegates widely represented the key target groups as given below:

- Water stakeholders in general [Consumer groups; farmer associations; in-stream interests (including fisheries); NGOs; industry, mining, forestry; medical profession (water \& health); municipalities; tourism; journalists]

- Decision-makers [politicians in Governments (federal/state); policy-makers in Departments of Water (Management) and the Environment (pollution control); industrial leaders]

- Water managers [municipal engineers; irrigation engineers; water supply and sanitation specialists; wastewater treatment specialists]

- Scientists [hydrologists; ecologists; social scientists; legal scientists].

The Minister of Water Affairs and Forestry, South Africa, Mrs LB Hendricks, extended a warm welcome to all attendees and hailed the convergence of all the separate disciplines under one roof as the sure path to a holistic understanding of the true meaning of an integrated catchment management approach. She elegantly captured the HELP approach as below:

'South Africa and the developing world, mainly in the South, generally have much to teach the developed countries (i.e. North), and on the other hand the developing countries (i.e. South) have much to learn from the developed countries in a two-way process. Such learning and shared experiences could greatly benefit our attempts as a global community to improve the sustainable management of our water resources in a truly integrated manner.'

\section{Overview of this special issue}

Peer reviewed papers from the Symposium included in this special edition include examples of how HELP basins have achieved real solutions in real catchments while working with real people facing complex challenges. The paper by Van Koppen (2008) reports a critical analysis of the continuities and changes in water management in the Olifants basin after the first decade of implementation of the National Water Act. Anderson et al. (2008) provide details of how participatory scenario modelling can lead to effective stakeholder dialogues in the Motala Ström River basin. Fenemore et al. (2008) have illustrated how Motueka catchment stakeholders have been engaged in longer 
term collaboration to implement integrated water resource management.

Hooper (2008) reports concept of covenant as a social contract for harnessing mutual trust and obligation between stakeholders for implementation of integrated river basin management. Ganoulis et al. (2008) share an excellent example of stakeholder engagement in the transboundary water resources management in the Mesta/Nestos basin. Stickney (2008) and Modley (2008) share examples from Lake Champlain on alternatives to legislation and regulation to inspire watershed protection and management of aquatic invasive species through rapid response planning partnerships.

Christoph et al. (2008) report results on the IMPETUS project utilising an integrated approach to the efficient management of water resources in West Africa offering a range of options for sustainable management of the hydrological cycle. Rhode et al (2008) provide insights into integrated nutrient transport modelling to underpin implementation of the European Water Framework Directive (WFD) to protect and enhance the status of aquatic and terrestrial ecosystems in the highly polluted Weisse Elster River basin, a sub-catchment of the Saale basin (Germany)

Scatena et al. (2008) and Hearne et al. (2008) share ideas from Luquillo and Davo basins on how to implement HELP principles in basins with limited resources. Khan (2008) reports 'System Harmonisation' a new cross-disciplinary framework from Australia which effectively links water cycles with social, economic, cultural and legal aspects and can be useful in extending the HELP principles in other basins. Allan et al. (2008) show the practical application of system harmonisation for assessing social acceptability of management options for harmonising irrigation with environmental concerns in the Murrumbidgee catchment in Australia.

The experiences shared in this special volume and during the symposium clearly show that managing stakeholder empowerment is extremely complex and often results in a localised solution without a generic formula. This requires locally customised holistic 'ecosystems' approaches to manage multilevel stakeholder perspectives in catchments. Such approaches needs to be capable of incorporating a broader understanding of water scarcity, unequal water access and inadequate adaptive capacity and readily adaptable to emerging issues.

\section{Future challenges for HELPers}

Catchment level water resource management and planning is likely to be affected by a range of emerging issues such as:

- Climate change-poverty-water sector adaptations

- Water-poverty-environment nexus

- Energy-water-poverty nexus

- Demand for bio-fuels ensuing competition for land and water resources used for food production

- Globalisation and trade policies for food security

- The changing role of state and local actors in the water sector

- Gender and the feminisation of agriculture and other waterintensive sectors.

Currently these areas are less well understood and the HELP research and development community must re-orient itself accordingly to deliver to the needs of the society.

A locally customised holistic 'ecosystems' approach to capacity building can generate positive sum solutions for global stakeholders. Local capacity-building priorities are areas of work best handled at the river basin level; not a substitute for or derivative of global priorities, but these can complement national or global agenda. HELP regions must respond to the concerns that are felt in several countries therefore contributing to the regional sustainability agenda. In doing so they can increase the attractiveness of funding from national budgets or local donors, and to help convince potential partners to team up, and to further develop the network of organisations collaborating on capacity development projects of regional significance.

The local capacity-building and training priorities for the implementation of integrated water resource management must be expressed as a regional HELP agenda, to allow many partners to buy in along the research-to-development continuum, and to form collaborations where consortia, alliances, networks, and individual organisations may all find their place both to fund it and to benefit from it. In some sense, the regional HELP approach already operates through the regional coordinating units. The regional agenda must be embedded into the national agenda to derive support from a central source as well as to the global agenda to generate global dividends from regional activities. This would be a key challenge for the future of HELP initiative as the priorities of different regions will be difficult to compare, and it might be difficult for the sub-regions to identify shared concerns.

Regional training priorities are best expressed in terms of development problems that need to be addressed locally but regional synergies are still possible. For instance, many of the issues are similar in Eastern and Southern Africa; Central Asian countries also encounter some shared issues, post-USSR; shared issues in Indian and Pakistan Punjabs. However, capacity-building needs in environmental care through better water governance and management would be far greater in some settings than others, for example, in Africa.

The symposium highlighted that the major challenge for HELPers is to maintain positive momentum to keep communities interested by:

- Building cross-disciplinary models of intermediate complexity to optimise data availability for effective policy support

- Targeting data campaigns using low cost data acquisition technologies

- Documenting success stories and failures in modelling, stakeholder engagement and capacity building

- Linking infrastructure investments with local capacity building.

\section{Acknowledgments}

The Department of Water Affairs and Forestry (DWAF) South Africa, the International Water Management Institute (IWMI), the Water Research Commission (WRC), the Water Institute of Southern Africa (WISA) and the University of KwaZulu-Natal (UKZN) are gratefully thanked for supporting an excellent symposium. Scientific and administrative inputs of the members of the International and Local Organising Committees are highly appreciated. Mike Bonell's dedicated leadership as the previous Global Coordinator of the UNESCO HELP Programme was instrumental in ensuring the success of this symposium. The author undertook the editing responsibilities for this Special Volume while working at CSIRO and the Charles Sturt University Australia. 


\section{References}

ALLAN C, KHAN S and DAVIDSON B (2008) Assessing social acceptability of management options for harmonising irrigation with environmental concerns: A pilot study from the Murrumbidgee Valley, Australia. Water SA 34 (4) 517-522.

ANDERSSON L, OLSSON JA, ARHEIMER B and JONSSON A (2008) Use of participatory scenario modelling as platforms in stakeholder dialogues. Water SA 34 (4) 439-447.

ANDERSSON L, BONELL L, MOODY D (2004) Foreword, Special Volume on Hydrology for the Environment Life and Policy. Water Resour. Dev. 20 (3) 267-274.

CHRISTOPH M, FINK A, DIEKKRÜGER B, GIERTZ S, REICHERT $\mathrm{B}$ and SPETH P (2008) Impetus: Implementing HELP in the Upper Ouémé basin. Water SA 34 (4) 481-489.

FALKENMARK M, GOTTSCHALK L, LUNDQVIST J and WOUTERS P (2004) Towards integrated catchment management: increasing the dialogue between scientists, policy-makers and stakeholders. Water Resour. Dev. 20 (3) 297-309.

FENEMOR A, DEANS N, DAVIE T, ALLEN W, DYMOND J, KILVINGTON M, PHILLIPS C, BASHER L, GILLESPIE P, YOUNG R, SINNER J, HARMSWORTH G, ATKINSON M and SMITH R (2008) Collaboration and modelling - Tools for integration in the Motueka catchment, New Zealand. Water SA 34 (4) 448-455.

GANOULIS J, SKOULIKARIS H and MONGET JM (2008) Involving stakeholders in transboundary water resources management: The Mesta/Nestos 'Help' basin. Water SA 34 (4) 461-467.

GIBBONS M, LIMOGES H, NOWOTNY H, SCHWARTZMAN S, SCOTT P and TROW M (1994) The New Production of Knowledge: The Dynamics of Science and Research in Contemporary Societies. Sage Publications, London.

HEARNE D, GAMBOA R and MONSANTO VM (2008) From ideas to action: A review of implementing HELP principles in river basins with limited resources and capacity. Water SA 34 (4) 504-511.

HOOPER BP (2008) Covenant action to facilitate integrated river basin management. Water SA 34 (4) 456-460.

INTERNATIONAL HYDROLOGICAL PROGRAMME: Technical Documents in Hydrology, No 44 (2001) 'The design and implementation strategy of the HELP initiative'. UNESCO, Paris.

KHAN S (2008) Extending the HELP approach through the system harmonisation philosophy. Water $S A 34$ (4) 512-516.

KHAN S (2004) Integrating hydrology with environment, livelihood and policy issues - the Murrumbidgee Model. Special Volume on Hydrology for the Environment Life and Policy. Water Resour. Dev. 20 (3) 415-429.

MODLEY MD (2008) Aquatic invasive species rapid response planning partnerships in the Lake Champlain basin: Bridging international, political, social, and economic gaps. Water SA 34 (4) 476-480.

RODE M, KLAUER B, PETRY D, VOLK M, WENK G and WAGENSCHEIN D (2008) Integrated nutrient transport modelling with respect to the implementation of the European WFD: The Weisse Elster case study, Germany. Water SA 34 (4) 490-496.

SCATENA FN, ORTIZ-ZAYAS JR and BLANCO-LIBREROS JF (2008) Helping HELP with limited resources: The Luquillo experience. Water SA 34 (4) 497-503.

SCHULZE R, HORAN M, SEETAL A and SCHMIDT E (2004) Roles and perspectives of the policy-maker, affected water sector and scientist in integrated water resources management: a case study from South Africa. Water Resour. Dev. 20 (3) 297-309.

STICKNEY M (2008) Building bridges, fording streams, reaching agreement in the Lake Champlain basin: Alternatives to legislation and regulation rooted in citizen and science-based approaches to inspire watershed protection. Water SA 34 (4) 468-475.

VAN KOPPEN B (2008) Redressing inequities from the past from a historical perspective: The case of the Olifants basin, South Africa. Water SA 34 (4) 432-438. 